\title{
Carbon footprint of dairy goat milk production in New Zealand
}

\author{
Kimberly Robertson, ${ }^{1}$ Wymond Symes, and Malcolm Garnham \\ Catalyst Ltd., PO Box 37228, Christchurch 8245, New Zealand
}

\begin{abstract}
The aim of this study was to assess the cradle-tofarm gate carbon footprint of indoor and outdoor dairy goat farming systems in New Zealand, identifying hotspots and discussing variability and methodology. Our study was based on the International Organization for Standardization standards for life cycle assessment, although only results for greenhouse gas emissions are presented. Two functional units were included: tonnes of $\mathrm{CO}_{2}$-equivalents $\left(\mathrm{CO}_{2} \mathrm{e}\right)$ per hectare (ha) and kilograms of $\mathrm{CO}_{2} \mathrm{e}$ per kilogram of fat- and proteincorrected milk (FPCM). The study covered 5 farms, 2 farming systems, and $3 \mathrm{yr}$. Two methods for the calculation of enteric methane emissions were assessed. The Lassey method, as used in the New Zealand greenhouse gas inventory, provided a more robust estimate of emissions from enteric fermentation and was used in the final calculations. The alternative dry matter intake method was shown to overestimate emissions due to use of anecdotal assumptions around actual consumption of feed. Economic allocation was applied to milk and co-products. Scenario analysis was performed on the allocation method, nitrogen content of manure, manure management, and supplementary feed choice. The average carbon footprint for the indoor farms $(\mathrm{n}=3)$ was $11.05 \mathrm{t}$ of $\mathrm{CO}_{2} \mathrm{e} / \mathrm{ha}$ and $0.81 \mathrm{~kg}$ of $\mathrm{CO}_{2} \mathrm{e} / \mathrm{kg}$ of FPCM. For the outdoor farms $(\mathrm{n}=2)$, the average was $5.38 \mathrm{t}$ of $\mathrm{CO}_{2} \mathrm{e} / \mathrm{ha}$ and $1.03 \mathrm{~kg}$ of $\mathrm{CO}_{2} \mathrm{e} / \mathrm{kg}$ of FPCM. The average for all 5 farms was $8.78 \mathrm{t}$ of $\mathrm{CO}_{2} \mathrm{e} / \mathrm{ha}$ and $0.90 \mathrm{~kg}$ of $\mathrm{CO}_{2} \mathrm{e} / \mathrm{kg}$ of FPCM. The results showed relatively high variability due to differences in management practices between farms. The 5 farms covered $10 \%$ of the total dairy goat farms but may not be representative of an average farm. Methane from enteric fermentation was a major emission source. The use of supplementary feed was highly variable but an important contributor to the carbon footprint. Nitrous oxide can contribute up to $18 \%$ of emissions. Indoor goat farming systems pro-
\end{abstract}

Received November 13, 2014.

Accepted April 3, 2015.

${ }^{1}$ Corresponding author: kimberly.robertson@catalystnz.co.nz duced milk with a significantly higher carbon footprint per area of land farmed compared with outdoor farming systems, although the 2 systems were not significantly different when results were expressed per kilogram of FPCM, at $0.81 \mathrm{~kg} \mathrm{CO}$ e and $1.03 \mathrm{~kg} \mathrm{CO} \mathrm{CO}_{2} \mathrm{e}$ per $\mathrm{kg}$ of FPCM, respectively. Both systems had footprints less than other reported dairy goat carbon footprints and on par with those for New Zealand dairy cows. The methodology used to determine enteric methane is important for an accurate and meaningful assessment. The choice of manure management system and supplementary feed can substantially affect the carbon footprint.

Key words: carbon footprint, dairy goat, greenhouse gas emissions

\section{INTRODUCTION}

Climate change caused by human activities has been identified as one of the greatest challenges facing countries, governments, business, and individuals. It is extremely likely that human influence has been the dominant cause of the warming since the mid-20th century, and continued emissions of greenhouse gases (GHG) will increase warming (IPCC, 2013).

In New Zealand (unlike other industrialized countries), almost half of the GHG emissions are due to agriculture, largely from enteric fermentation and nitrous oxide emissions from soils (Ministry for the Environment, 2013). Dairy goats make a relatively small contribution to emissions due to the low numbers compared with the major livestock sectors (dairy, beef, sheep, and deer). However, all production systems need to reduce their carbon footprint (GHG emissions associated with a particular product, service, or organization) if humanity hopes to keep climate change within acceptable limits. The aim of the current study was to evaluate New Zealand dairy goat carbon footprint, address methodological issues, identify hotspots, and provide farmers with information about how management decisions can affect the carbon footprint of goat milk production.

A methodology for carbon footprinting of dairy cow milk production systems has been developed (International Dairy Federation, 2010) and several studies 


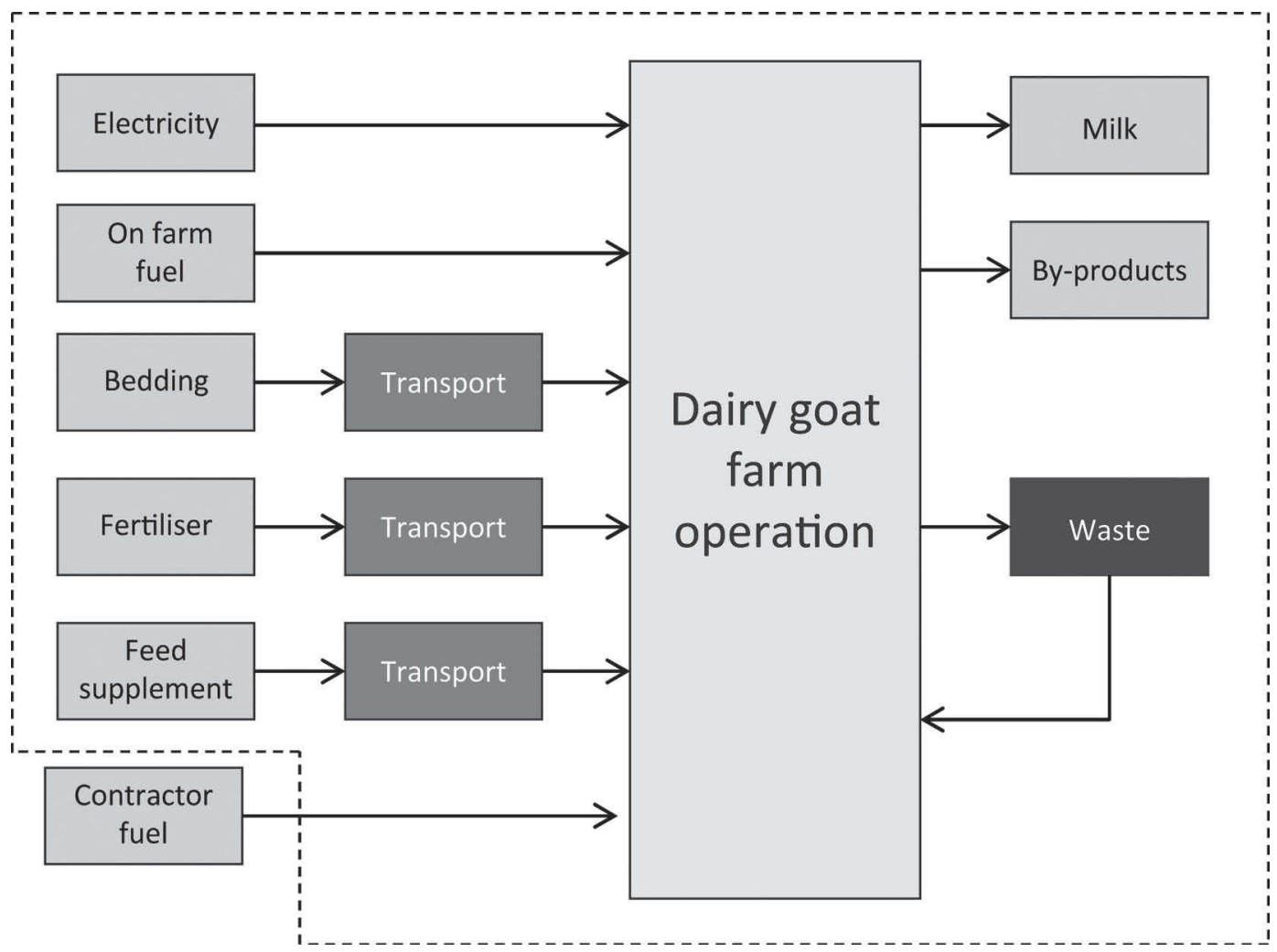

Figure 1. Dairy goat milk production system boundary, from cradle to gate.

have been carried out to assess the carbon footprint of different management systems. However, no standard methodology for dairy goat milk production exists.

Two types of goat farming systems are used in New Zealand, with goats being housed indoors or outdoors. Our study investigated the cradle-to-farm gate carbon footprint of both systems. The goals of our study were to estimate the carbon footprint of indoor and outdoor dairy goat farms and determine whether they are different; to look at the effect of year on the carbon footprint and variability between farms; and identify data gaps and methodological issues and identify hotspot areas of the supply chain that have the highest carbon footprint. Our study was based on the International Organization for Standardization standards for life cycle assessment [ISO, 2006a (14040) and ISO, 2006b (14044)], although we present results only for GHG.

\section{METHODS}

\section{System Description}

The product system is the on-farm production of goat milk from cradle to farm gate (Figure 1). All farm inputs and outputs were included except contractor fuel and pesticides. Purchased supplementary feed included dried distillers grain, brewers grain, maize grain, maize silage, pasture silage, maize-pea premix, wheat bran pellets, cotton seed meal, palm kernel, broll (a by-product of wheat milling), molasses, condensed distillers syrup, manufactured goat feed pellets, milk replacer, and cow milk. Each farm's use of purchased feed differed between years, and all used between 3 and 11 types of the purchased feed listed.

Indoor systems house goats in open-sided barns and feed is brought to them daily. Waste feed, along with barn manure consisting of feces, urine, and the woodchips that lines the barn floors, is removed periodically, in some cases stockpiled, then spread on farm to degrade. Feed typically consists of pasture grown on farm that is cut and carried to the barns, along with some or all of the following supplementary feed: pasture or maize silage, lucerne, grains, brewing and distillery byproducts (e.g., brewers grain), and molasses.

In outdoor farming systems, the goats live and graze on farm paddocks, and the majority of their energy requirements are provided by the pasture they graze. Some supplementary feed may be supplied, and these will be similar to those supplemented in indoor farming systems. With outdoor farming, manure management is not necessary, as feces and urine degrade into the soil of the paddocks where they fall. 
In both systems, goats are walked to the milking shed twice daily for milking. Both systems use bucks for mating and have approximately 5 bucks per 100 does. Each doe produces on average 2.1 kids each year and several of these are kept as herd replacements to join the milking herd at the age of 2 . Kids not retained on farm, along with culled bucks and does, are sold. Goat numbers, as assessed in our study and presented in Tables 1 and 2, represent an annual average. Both systems use fertilizer to improve pasture production (although it is not applied every year) and dairy shed effluent is either applied directly to pasture or stored in holding ponds for a period of time and then applied to pasture.

\section{Functional Unit}

Results are presented in 2 functional units: 1 ha of land used and $1 \mathrm{~kg}$ of fat- and protein-corrected milk (FPCM) leaving the farm gate. The FPCM is calculated by multiplying milk production by the ratio of the energy content of a specific milk by the energy content of standard milk with $4 \%$ fat and $3.3 \%$ true protein content. The energy content of milk with known fat and protein content is calculated by

$$
\begin{gathered}
\text { Milk energy }(\mathrm{Mcal} / \mathrm{kg})=(0.0929 \times \text { fat \% }) \\
+(0.0588 \times \text { protein } \%)+0.192(\text { Clark et al., } 2001) .
\end{gathered}
$$

For dairy goat milk, the energy content of standardized milk is $0.64 \mathrm{Mcal} / \mathrm{kg}$ (Colin Prosser, DGC NZ Ltd., Hamilton, New Zealand, personal communication). By dividing the coefficients above by the standard milk energy content, the final equation for calculating goat FPCM is

FPCM $(\mathrm{kg})=$ raw milk $(\mathrm{kg}) \times[0.145 \times$ fat content

$$
(\%)+0.092 \times \text { protein content }(\%)+0.3] \text {. }
$$

The fat and protein content used to calculate FPCM is farm- and year-specific; see Tables 1 and 2 for details.

\section{Data}

Three years (a year covers the period from July 1 to June 30) of primary data were collected from 3 indoor and 2 outdoor dairy goat systems. The indoor farm data covered years 2009-2010, 2010-2011, and 20112012. The outdoor farm data were collected for years 2010-2011, 2011-2012, and 2012-2013. This covered 6\% of indoor farms, $22 \%$ of outdoor farms, and $9 \%$ of all farms within a 59-farm cooperative for which our study was undertaken (in 2013). These farms were chosen due to data availability and willingness of the farmers to participate in the study. Compared with industry averages, collectively these farms milk fewer animals per farm (583 vs. 625$)$ and have lower milk solids production per head (56 vs. $75 \mathrm{~kg}$ ). All study farms were located in the Waikato region of New Zealand, within a 60-km transport distance of the factory that processes the milk. Area, livestock milk production, feed, and other inputs of the farms are summarized in Tables 1 and 2 .

\section{Calculation of Embodied Carbon Dioxide Emissions}

Greenhouse gas emissions from farm inputs, including, fertilizer, fuel, electricity, and bedding, were calculated using life cycle assessment emission factors listed in Table 3. These were then converted to $\mathrm{CO}_{2}$ equivalents $\left(\mathbf{C O}_{2} \mathbf{e}\right)$ using the Intergovernmental Panel on Climate Change (IPCC) global warming potentials (GWP; IPCC, 1995).

Our study was performed in 2013, before ISO (2013) standard 14067 on product carbon footprinting was available. Without this standard for guidance on GWP, we chose IPCC second assessment GWP to be consistent with methodology used in the New Zealand GHG inventory.

\section{Supplementary Feed}

Indoor farms, and to a lesser extent outdoor farms, use a large amount of purchased supplementary feed. Use between farms and between years varies greatly and appears dependent on stock numbers, milk productivity, and the relative amount of feed grown on farm, which itself is dependent on growing conditions such as weather. In the current study, 11 different feeds were used across the 5 farms, although 3 feeds contributed $80 \%$ of the total feed (Table 4). Most feeds are byproducts of other processes; for example, brewers grain is a by-product of beer production that is seen as a waste product. A Feedprint (Vellinga et al., 2013a,b) emission factor of zero is used for brewers grain, and anecdotal evidence suggests that brewers grain is also a waste product in New Zealand. Transport is the only source of emissions for brewers grain. In New Zealand, brewers grain is not currently fully used but if it were unavailable to dairy goat farmers, other higher-emission feeds would be required. Where allocation was required, economic allocation was used as per the International Dairy Federation guidelines (International Dairy Federation, 2010). Dairy goat blend is a product made in New Zealand from several by-products. Information on the product mix, supplier, and transport of the inputs was used to estimate the carbon footprint of the feed. 
ROBERTSON ET AL.

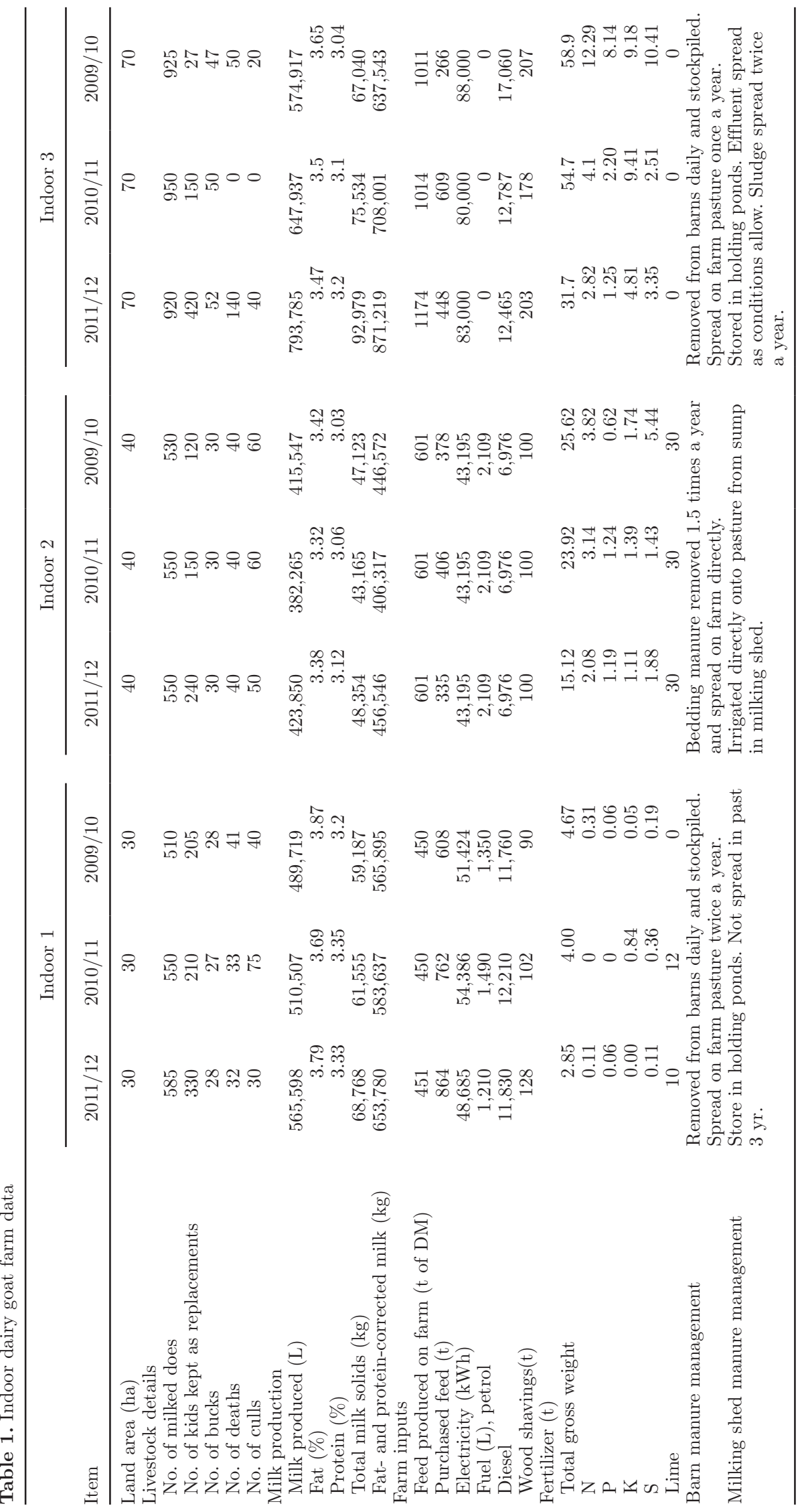


Table 2. Outdoor dairy goat farm data

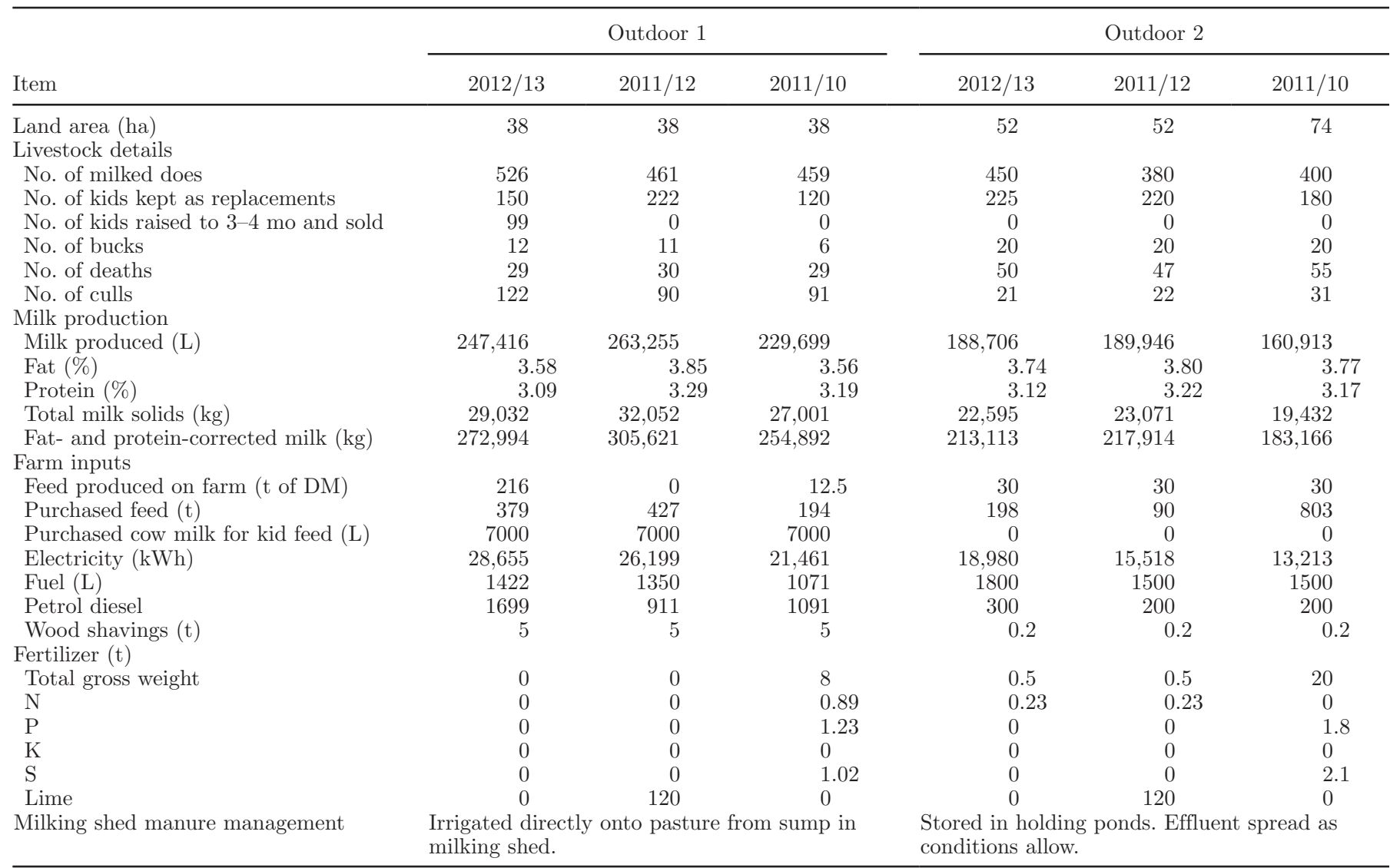

Palm kernel expeller is no longer used, but at the time of the study, 1 farm used it for $1 \mathrm{yr}$, so it was included. Details of the supplementary feed emission factors are provided in Table 5. Many of the emission factors are New Zealand-specific; where New Zealand values are not available, Feedprint (Vellinga et al., 2013a,b), a database of feed carbon footprints developed in the Netherlands, was used. Feedprint emission factors were applied to broll (a by-product of wheat flour milling) and avon (a by-product of starch or glucose manufac-

Table 3. Emission factors for farm inputs

\begin{tabular}{|c|c|c|}
\hline Emission source & Emission factor & Reference \\
\hline Natural gas & $61.00 \mathrm{~kg}$ of $\mathrm{CO}_{2} \mathrm{e} / \mathrm{GJ}$ & Barber (2009) \\
\hline \multicolumn{3}{|l|}{ Fertilizer manufacture } \\
\hline $\mathrm{N}$ & $3.38 \mathrm{~kg}$ of $\mathrm{CO}_{2} \mathrm{e} / \mathrm{kg}$ & Wells (2001) \\
\hline $\mathrm{P}$ & $0.96 \mathrm{~kg}$ of $\mathrm{CO}_{2} \mathrm{e} / \mathrm{kg}$ & Wells (2001) \\
\hline Lime manufacture & $4.00 \mathrm{~kg}$ of $\mathrm{CO}_{2} \mathrm{e} / \mathrm{t}$ & Ledgard et al. (2011) \\
\hline Wood shavings manufacture & $5.864 \mathrm{~kg}$ of $\mathrm{CO}_{2} \mathrm{e} / \mathrm{t}$ & $\begin{array}{l}\text { Sandilands et al. (2009); NZ sawn timber life } \\
\text { cycle inventory data with } 10 \% \text { mass allocation } \\
\text { to shavings }\end{array}$ \\
\hline Transport by truck $(3.5-7.5 \mathrm{t}$, rigid $)$ & $0.722 \mathrm{~kg}$ of $\mathrm{CO}_{2} \mathrm{e} /$ tonne $(\mathrm{t}) \cdot \mathrm{km}$ & DEFRA $(2011)$ \\
\hline Transport by truck $(7.5-17 \mathrm{t}$, rigid $)$ & $0.468 \mathrm{~kg}$ of $\mathrm{CO}_{2} \mathrm{e} / \mathrm{t} \cdot \mathrm{km}$ & DEFRA (2011) \\
\hline Transport by truck ( $>17 \mathrm{t}$, rigid) & $0.236 \mathrm{~kg}$ of $\mathrm{CO}_{2} \mathrm{e} / \mathrm{t} \cdot \mathrm{km}$ & DEFRA (2011) \\
\hline
\end{tabular}


turing, derived from maize), covering $5 \%$ of the total supplementary feed used over the 3 yr. These emission factors reflect the carbon footprint of feeds produced or used in the Netherlands; New Zealand-produced feeds may have a different carbon footprint. Due to the low use of these feeds, the effect of any emission factor differences on results is likely to be small. Transport of feed from the producer or manufacturer to a New Zealand supplier and then to the dairy goat farm is included.

\section{Livestock Emissions}

Enteric Methane. Methane emissions occur because of enteric fermentation in the goat digestion system. The amount of $\mathrm{CH}_{4}$ released depends on the age and weight of the animal, the quality and quantity of feed, the energy expenditure of the animal, and the amount of feed consumed. Two options for estimation of $\mathrm{CH}_{4}$ emission from enteric fermentation were used to analyze the effect of methodology choice on results.

In method 1, emissions were determined based on calculated herd DMI and a factor of $20.9 \mathrm{~g}$ of $\mathrm{CH}_{4} /$ $\mathrm{kg}$ of DM (Wheeler, 2012). This method was applied to the indoor system only. The DMI was calculated by multiplying the known DM content of individual feeds by estimated feed consumption. In doing so, several assumptions were made; for instance, DM content of pasture and maize silage was assumed to be 25 and $35 \%$, respectively, and $\mathrm{DM}$ content of concentrate supplementary feeds was assumed to be $90 \%$.

For pasture grown on indoor farms, we assumed that all available pasture was harvested as cut-and-carry feed or silage and all was fed out. The exception was indoor farm 3, where actual harvest and utilization data was applied. An average annual pasture production figure of $15 \mathrm{t}$ of DM/ha (Holmes et al. 2007) was applied to all indoor farms except indoor farm 3, for which actual production figures were provided.

The following utilization (i.e., consumption) rates were assumed in the calculation of DMI levels: $80 \%$ for cut-and-carry grass, lucerne, or other farm-grown crops and silage; $90 \%$ for supplementary feeds including concentrates. The amount of supplementary feed used and pasture production is relatively well known for each of the indoor farms. The data on feed utilization are anecdotal and have not been measured in New Zealand dairy goats. Pasture utilization by goats on outdoor farms is difficult to estimate, as they are very selective grazers; for this reason, a second method was needed to check the results.

In method 2, the New Zealand GHG inventory (Ministry for the Environment, 2013) used a method developed by Lassey (2012) to estimate enteric $\mathrm{CH}_{4}$

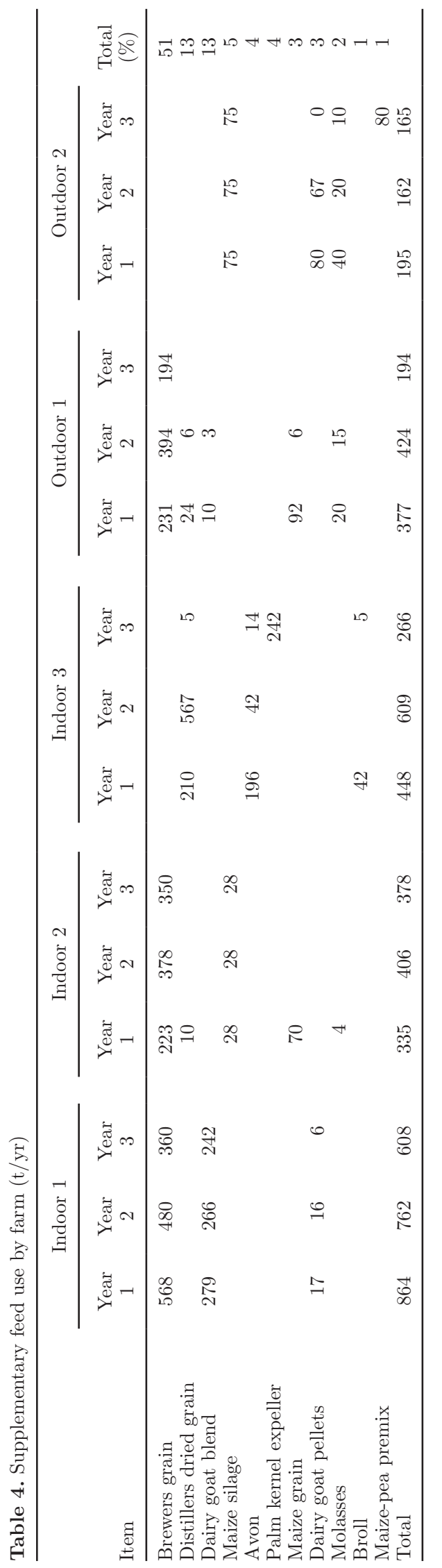


Table 5. Supplementary feed carbon emission factors [EF; $\mathrm{kg}$ of $\mathrm{CO}_{2}$-equivalents (e)/t]

\begin{tabular}{|c|c|c|c|c|}
\hline Feed type & Detail & $\mathrm{EF}$ & Allocation & Reference \\
\hline Dried distillers grain & $\begin{array}{l}\text { By-product of bioethanol production } \\
\text { (from grains or brewing) in Australia }\end{array}$ & 362 & Economic & $\begin{array}{l}\text { National Renewable Energy Laboratory } \\
\text { (2014), plus transport from Australia }\end{array}$ \\
\hline Dairy goat blend & $\begin{array}{l}\text { Made in New Zealand from a mix of } \\
\text { avon, hominy meal, DDG and broll }\end{array}$ & 574 & Economic & $\begin{array}{l}\text { Based on input and transport, } \\
\text { information from manufacture }\end{array}$ \\
\hline Avon & $\begin{array}{l}\text { By-product from starch/glucose } \\
\text { manufacturing, derived from maize } \\
\text { produced in New Zealand }\end{array}$ & 734 & Economic & $\begin{array}{l}\text { FeedPrint (Vellinga et al., 2013a,b), } \\
\text { economic allocation and transport }\end{array}$ \\
\hline Palm kernel expeller & $\begin{array}{l}\text { By-product of palm oil production in } \\
\text { SE Asia }\end{array}$ & 800 & Economic & Sonesson et al. (2009) \\
\hline \multirow{3}{*}{$\begin{array}{l}\text { Maize grain } \\
\text { Dairy goat lift pellets } \\
\text { Molasses }\end{array}$} & From New Zealand maize & 190 & \multirow[t]{2}{*}{ None } & MAF (2011) \\
\hline & Manufactured in New Zealand & 574 & & Assumed the same as Dairy goat blend \\
\hline & $\begin{array}{l}\text { By product of sugar production in } \\
\text { Australia }\end{array}$ & 148 & Mass & Renouf and Wegener (2011) \\
\hline Maize silage & From maize produced in New Zealand & 125 & None & MAF (2011) \\
\hline
\end{tabular}

emissions. As part of a review of the emission factors used in the New Zealand national GHG inventory for goats, Lassey (2012) determined the annual energy requirements of subpopulations of goats, including dairy goats, to estimate DMI levels, and developed emission factors that calculated enteric $\mathrm{CH}_{4}$ per goat class per year. These emission factors were applied to goat numbers for both the indoor and outdoor systems as an alternative method for calculating enteric methane emissions. The following factors were used: $9.60 \mathrm{~kg}$ of $\mathrm{CH}_{4} /$ herd per year for milking does; $7.35 \mathrm{~kg}$ of $\mathrm{CH}_{4} /$ herd per year for bucks; and $1.50 \mathrm{~kg}$ of $\mathrm{CH}_{4} /$ herd per year for replacement kids.

Emissions were also estimated using the IPCC default method and emission factor for goat enteric fermentation to provide some overall context. For each method, $\mathrm{CH}_{4}$ emissions were converted to $\mathrm{CO}_{2} \mathrm{e}$ on the basis of methane 100-yr global warming potential. One unit of $\mathrm{CH}_{4}$ is equivalent to 21 units of $\mathrm{CO}_{2}$ (IPCC, 1995).

Manure Methane. Manure is composed principally of organic material. When manure decomposes in the absence of oxygen, bacteria produce $\mathrm{CH}_{4}$. The amount of $\mathrm{CH}_{4}$ emitted is related to the amount of manure subject to anaerobic decomposition. Carlson et al. (2010) estimates dairy goats produce on average $1 \mathrm{t}$ of manure a year with a DM content of $35 \%$. Anaerobic decomposition occurs at different levels depending on how the manure is managed.

For manure in holding pens that is collected and applied directly to pasture, an emission factor of $0.691 \mathrm{~g}$ of $\mathrm{CH}_{4} / \mathrm{kg}$ of manure DM was applied (Wheeler, 2012). The same emission factor was applied to outdoor-farmed goats whose manure falls directly onto the pasture.
For indoor farms where waste is stockpiled, manure that is removed from the pens and stored produces up to 7 times more methane if uncovered, and 14 times more if covered (Wheeler 2012). This was expressed as $\mathrm{g}$ of $\mathrm{CH}_{4}=\mathrm{kg}$ of manure $\mathrm{DM} \times 2$ (months in storage, maximum 7) $\times 0.691$ for covered piles; and $\mathrm{g}$ of $\mathrm{CH}_{4}=$ $\mathrm{kg}$ of manure $\mathrm{DM} \times($ months in storage, maximum 7$)$ $\times 0.691$ for uncovered piles.

Dairy shed effluent applied directly from sump to pasture was treated as manure applied directly to pasture. Dairy shed effluent stored in holding ponds was treated as uncovered, stored manure. Once calculated, $\mathrm{CH}_{4}$ emissions were converted to $\mathrm{CO}_{2} \mathrm{e}$ based on methane's 100-yr GWP.

Nitrous Oxide. Nitrous oxide is produced during the breakdown of goat manure or nitrogen-containing fertilizer and is categorized as either direct or indirect, the latter being $\mathrm{N}_{2} \mathrm{O}$ produced from the nitrogen that is leached or volatized. Direct $\mathrm{N}_{2} \mathrm{O}$ emissions from manure depend on the amount of nitrogen in the manure and the method of disposal. For our study, $\mathrm{N}$ values of $13.6,10.4$, and $2.2 \mathrm{~kg}$ /head per year were applied for does, bucks, and kids, respectively (Lassey, 2012). Four percent of the manure was produced in the milking shed whereas the remainder fell in the barn or outdoors. Primary data were collected on disposal methods (Tables 1 and 2). Milking shed manure was either stored in a pond, applied directly to pasture, or a mixture of both disposal options. Barn manure (indoor system) was either stored in uncovered piles or spread directly on pasture. In the outdoor system, manure fell on the pasture in situ. The Ministry for the Environment (2013) emission factors were applied to 
Table 6. Nitrous oxide emission factors (Ministry for the Environment, 2013)

\begin{tabular}{ll}
\hline Emission source & \multicolumn{1}{c}{ Emission factor } \\
\hline $\mathrm{N}_{2} \mathrm{O}$ direct from pond $\mathrm{N}$ & $0.001 \mathrm{~kg}$ of $\mathrm{N}_{2} \mathrm{O}-\mathrm{N} / \mathrm{kg}$ of $\mathrm{N}$ \\
$\mathrm{N}_{2} \mathrm{O}$ direct from land application of $\mathrm{N}$ & $0.01 \mathrm{~kg}$ of $\mathrm{N}_{2} \mathrm{O}-\mathrm{N} / \mathrm{kg}$ of $\mathrm{N}$ \\
$\mathrm{N}_{2} \mathrm{O}$ direct during storage & $0.02 \mathrm{~kg}$ of $\mathrm{N}_{2} \mathrm{O}-\mathrm{N} / \mathrm{kg}$ of $\mathrm{N}$ \\
$\mathrm{N}_{2} \mathrm{O}$ indirect from leaching & $0.025 \mathrm{~kg}$ of $\mathrm{N}_{2} \mathrm{O}-\mathrm{N} / \mathrm{kg}$ of $\mathrm{N}$ \\
$\mathrm{N}_{2} \mathrm{O}$ indirect from volatization & $0.01 \mathrm{~kg}$ of $\mathrm{N}_{2} \mathrm{O}-\mathrm{N} / \mathrm{kg}$ of $\mathrm{N}$ \\
\hline
\end{tabular}

indoor and outdoor systems for direct $\mathrm{N}_{2} \mathrm{O}$ emissions from pond, land application, and storage (Table 6).

Indirect $\mathrm{N}_{2} \mathrm{O}$ emissions are produced from the nitrogen in manure and applied fertilizer that is leached or volatized. In line with the methodology used in the New Zealand national inventory report (Ministry for the Environment, 2013), our study assumed that the fraction of total nitrogen in manure leached and volatized was 7 and $10 \%$, respectively, with the emission factors in Table 6 then applied. One unit of $\mathrm{N}_{2} \mathrm{O}$ emissions is equivalent to 310 units of $\mathrm{CO}_{2}$ (IPCC, 1995).

\section{Omissions}

Due to lack of reliable data and likely lack of utility (contributing less than 1\% to the carbon footprint), the following cradle-to-farm gate emission sources were omitted from the study:

1. Transport of bedding and fertilizer from production site to supplier; only transport from the supplier's warehouse to farm (via depot or regional store if applicable) was included.

2. Manufacture and disposal of feed packaging (e.g., bags for purchased feeds or polyethylene wraps for silage).

3. Pesticides and herbicides.

4. Contractor fuel, which relates to the use of external farm contractors for activities that include pasture or crop establishment and harvesting, fertilizer application, and manure or effluent spreading. Contractors were used sparingly and are expected to contribute minimally to the overall footprint. Data were only available for 1 farm in our study and contributed less than $1 \%$ of total farm emissions.

5. Livestock that were culled or died naturally, as data were not available on the proportion of the year they were alive.

\section{Allocation}

Where other stock exists on a farm, shared inputs such as fertilizer were allocated according to grazing area. For instance, 8 of the 48 ha in indoor farm 2 was used for rearing beef cattle. Fertilizer was applied evenly to the entire property with no differentiation between the cattle and goat cut-and-carry paddocks; therefore, fertilizer inputs were allocated to each according to area. When allocating emissions between milk and byproducts, economic allocation principles were applied based on the following: culled animals were sold for $\mathrm{NZ} \$ 5$ to $\$ 40$ each, depending on farm; kids reared to the age of 3 to $4 \mathrm{mo}$ and sold had a monetary value of NZ\$300 each; milk had a value of $\mathrm{NZ} \$ 15 / \mathrm{kg}$ of milk solids; no other income sources were evident within the boundary of the study; and allocation of the carbon footprint to milk varied by farm and year at 93 to $100 \%$ with an average of $99 \%$.

\section{Scenario and Sensitivity Analysis}

Allocation to Milk and Meat. International Dairy Federation (2010) suggests a physical approach to allocation between milk and meat that is based on the underlying use of feed energy by dairy cows to produce milk and meat. The following formula was developed specifically for dairy cows. We applied this to the indoor farms using dairy goat farm-specific meat and milk information to assess the effect of allocation method choice on the carbon footprint.

$$
\begin{aligned}
& \text { Milk allocation factor }=1-5.7717 \\
& \quad \times(\mathrm{kg} \text { of meat } / \mathrm{kg} \text { of milk }),
\end{aligned}
$$

where $\mathrm{kg}$ of meat $=$ no. of culls $\times 38$ (assumed weight of cull, $\mathrm{kg}$ ), and $\mathrm{kg}$ of milk = kilograms of production of FPCM.

Nitrogen Content of Manure Waste. Nitrous oxide emissions are a function of the amount of $\mathrm{N}$ excreted by the goats and how the excretion is managed. The $\mathrm{N}$ content of barn manure is dependent on the quantity and type of feed the goats are eating and it would be more accurate to apply actual $\mathrm{N}$ figures to the calculations if these data were available. One farm in this study (indoor 1) had an independent analysis done on its barn manure in 2010. The $\mathrm{N}$ content of its barn manure was found to be higher than the default used at $21.7 \mathrm{~kg} / \mathrm{head}$ per year. The effect of this on the carbon footprint was analyzed.

Manure Management. The farms in our study used different strategies for managing their waste and barn manure. For farms that stockpiled significant quantities of barn waste for long periods, the emissions were significantly greater. Indoor farm 3 removed manure and waste from around feed stations daily and stockpiled it for disposal later. Once a year, the barns 
Table 7. Purchased feed scenarios (t)

\begin{tabular}{lccccc}
\hline Feed type & $\begin{array}{c}\text { Actual } \\
\text { purchased } \\
\text { feed }\end{array}$ & $\begin{array}{c}\text { Scenario 1, } \\
50 \% \text { brewers } \\
\text { grain }\end{array}$ & $\begin{array}{c}\text { Scenario 2, } \\
100 \% \text { brewers } \\
\text { grain }\end{array}$ & $\begin{array}{c}\text { Scenario 3, } \\
50 \% \text { maize } \\
\text { grain }\end{array}$ & $\begin{array}{c}\text { Scenario 4, } \\
100 \% \text { maize } \\
\text { grain }\end{array}$ \\
\hline Brewers grain & - & 203 & 406 & - & - \\
Dried distillers grain & 210 & 105 & 0 & 105 & 0 \\
Avon & 196 & 98 & 0 & 98 & 0 \\
Broll & 42 & 42 & 42 & 42 & 42 \\
Maize grain & - & - & - & 203 & 406 \\
\hline
\end{tabular}

were cleaned out and the bedding and manure were spread on the farm along with the stockpiled waste. This scenario looks at the effect of the waste not being stockpiled and instead remains in the barn until removal and direct spreading. This reduces the time the manure is in anaerobic conditions and, therefore, methane production.

Supplementary Feed. The farms used a wide range of supplementary feed. Some supplementary feed had a much higher carbon footprint than others. Our sensitivity analysis used indoor farm 3 and 2011-2012 data and looked at the effect of replacing avon and dried distillers grains (feeds with high carbon footprints) at rates of 50 and $100 \%$ with brewers grain and maize grain (feeds low in embodied carbon; Table 7). It is important to note that changes to the diet may result in changes to the nitrogen content in the manure. However, in this scenario analysis and in the main study itself, we used a generic manure $\mathrm{N}$ content figure and this has not been investigated.

\section{RESULTS}

\section{Mean Carbon Footprint of Indoor and Outdoor Dairy Goat Farms}

The carbon footprints of the 5 dairy goat farms differed by farming system. Using method 2 for enteric $\mathrm{CH}_{4}$ emission calculations as the preferred method (see the Enteric Methane section), the outdoor farms had a significantly lower total carbon footprint per hectare of land use but a higher (although not significantly different) carbon footprint per kilogram of FPCM compared with indoor farms (Table 8) in our study. The average carbon footprint for the indoor farms was $11.05 \mathrm{t}$ of $\mathrm{CO}_{2} \mathrm{e} / \mathrm{ha}$ and $0.81 \mathrm{~kg}$ of $\mathrm{CO}_{2} \mathrm{e} / \mathrm{kg}$ of FPCM. For the outdoor farms, the average was $5.38 \mathrm{t}$ of $\mathrm{CO}_{2} \mathrm{e} / \mathrm{ha}$ and $1.03 \mathrm{~kg}$ of $\mathrm{CO}_{2} \mathrm{e} / \mathrm{kg}$ of $\mathrm{FPCM}$.

\section{Carbon Footprint Variability Between Farms and Year}

As the results illustrate, variability was more evident between farms, with average farm results across all years ranging from 0.65 to $1.19 \mathrm{~kg}$ of $\mathrm{CO}_{2} \mathrm{e} / \mathrm{kg}$ of FPCM (Figure 2). The annual averages also varied for each farming system, with results ranging from 0.84 to $1.07 \mathrm{~kg} \mathrm{CO} \mathrm{CO}_{2} \mathrm{e} / \mathrm{kg}$ of FPCM. Over the 4-season period of the assessment, the Waikato region experienced drought-like conditions twice once in late 2010 and again, more severely, in early 2013. This may account for some of the within-farm variability. However, these results imply that management practices had a greater influence on the carbon footprint than annual changes, although both need to be taken into account in calculating the carbon footprint. Differences in fertilizer use contributed to variability, with fertilizer not applied every year.

\section{Hotspots}

Methane emissions from enteric fermentation were a major contributor to the carbon footprint on all farms, contributing 26 to $43 \%$ of emissions for indoor farms and 48 to $56 \%$ for outdoor farms (Figure 2). Supplementary feed production and transport also contributed significantly, at 13 to $50 \%$ of emissions. Large quantities of lime were applied to both outdoor farms

Table 8. Indoor and outdoor system carbon footprint comparison

\begin{tabular}{|c|c|c|c|c|c|c|c|c|}
\hline \multirow[b]{2}{*}{ Item } & \multicolumn{4}{|c|}{$\begin{array}{l}\mathrm{kg} \text { of } \mathrm{CO}_{2} \text {-equivalents } / \mathrm{kg} \text { of fat- } \\
\text { and protein-corrected milk }\end{array}$} & \multicolumn{4}{|c|}{$\mathrm{t}$ of $\mathrm{CO}_{2}$-equivalents/ha } \\
\hline & Mean & $\mathrm{SD}$ & SEM & $P$-value & Mean & $\mathrm{SD}$ & SEM & $P$-value \\
\hline Indoor & 0.81 & 0.18 & 0.06 & 0.66 & 11.05 & 3.73 & 1.24 & 0.04 \\
\hline Outdoor & 1.03 & 0.20 & 0.08 & & 5.38 & 1.61 & 0.66 & \\
\hline Average & 0.089 & 0.21 & & & 8.73 & 4.12 & & \\
\hline
\end{tabular}




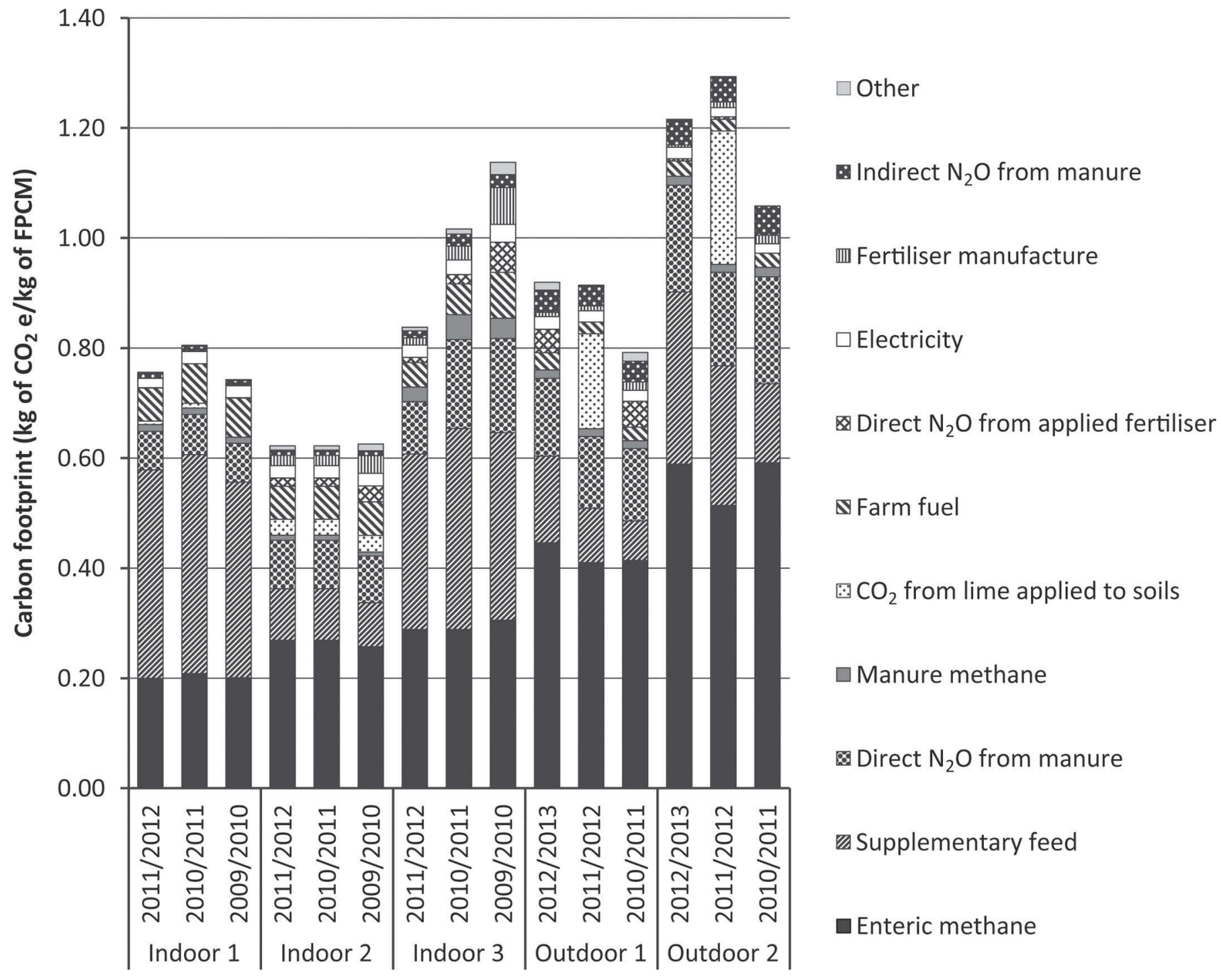

Figure 2. Dairy goat farm carbon footprint $\left[\mathrm{kg}\right.$ of $\mathrm{CO}_{2}$-equivalents (e)/ $\mathrm{kg}$ of fat- and protein-corrected milk (FPCM)].

in 2011-2012 (none in the other years), contributing $19 \%$ to the carbon footprint in that year and pushing the footprint up compared with the years before and after. The carbon footprint of direct $\mathrm{N}_{2} \mathrm{O}$ from manure management was also significant across all farms and years, contributing 9 to $18 \%$ of emissions.

\section{Supplementary Feed}

The use of supplementary feed can increase the carbon footprint of dairy goat milk production substantially depending on the amount used and the choice of feed. The carbon footprint of particular supplementary feeds varied greatly (Table 5). For example, brewers grain has a zero cradle-to-gate carbon footprint, as it is a waste by-product of the brewing industry with no eco- nomic value. Emissions are associated with transport of brewers grain. The farm and year (outdoor farm 1, yr 3 ) with the lowest supplementary feed carbon footprint used only brewers grain that year. Those farms or years where supplementary feed contributed substantially typically used feeds such as avon, distillers dried grains, and the dairy goat blend.

\section{Enteric Methane-Comparison of Methodologies}

Results of the comparison of enteric methane methodologies indicated that the choice of methodology has a significant effect on the enteric methane emissions and overall results (Table 9, Figure 3), with the DMI method producing substantially higher enteric methane values (average across all farms) than either the 
Table 9. Comparison of enteric methane emission factors

\begin{tabular}{lcc}
\hline Method & $\begin{array}{c}\text { Enteric fermentation } \\
\text { emission factor } \\
\left(\mathrm{kg} \text { of } \mathrm{CH}_{4} / \text { herd per year }\right)\end{array}$ & $\begin{array}{c}\text { Average enteric methane } \\
\text { emissions }\left(\mathrm{kg} \mathrm{of} \mathrm{CH}_{4} / \mathrm{kg}\right. \\
\text { of fat- }\end{array}$ \\
IPCC $(2006)$ & $5 \quad$ and protein-corrected milk) \\
Lassey & 9.60 milking does and 7.35 bucks & 0.171 \\
DMI & $15-17$ (implied emission factor) & 0.254 \\
\hline
\end{tabular}

IPCC (2006) default or Lassey (2012) methods. This is likely the result of overestimating the amount of DM consumed by the goats. Based on anecdotal industry estimates, we assumed that $80 \%$ of the pasture and crops fed out were consumed and $90 \%$ of the purchased concentrate feed was eaten. The large difference in results between the methodologies calls these assumptions into question. Without more reliable consumption data, this method is unreliable. For this reason, method 2, applying goat class-specific emission factors derived for the New Zealand national GHG inventory by Lassey (2012), is likely to provide a more realistic estimate of enteric methane emissions; we used method 2 to estimate enteric methane emissions for the carbon footprint results presented herein.

\section{Scenario Analysis}

Allocation to Milk and Meat. The International Dairy Federation (2010) allocation method provides allocation to milk of 90 to $100 \%$, with an average of $97 \%$. The average was slightly lower that the economic allocation used in the base case. The effect of the use of the International Dairy Federation allocation method on results was to reduce the average indoor farm carbon footprint from 0.81 (economic allocation) to 0.80 $\mathrm{kg}$ of $\mathrm{CO}_{2} \mathrm{e} / \mathrm{kg}$ of FPCM (physical causality allocation).

Nitrogen Content of Manure Waste. Increasing the $\mathrm{N}$ content of manure to $21.70 \mathrm{~kg} /$ head per year resulted in an increase in $\mathrm{N}_{2} \mathrm{O}$ emissions from manure of $127 \%$ (Table 10). The effect of this change on total farm emissions was a $13 \%$ increase.

Manure Management. For indoor farm 3 in 20112012, $\mathrm{CH}_{4}$ and direct and indirect $\mathrm{N}_{2} \mathrm{O}$ emissions from manure management amounted to 0.038 and $0.15 \mathrm{~kg}$ of $\mathrm{CO}_{2} \mathrm{e} / \mathrm{kg}$ of $\mathrm{FPCM}$, respectively. If the barn waste were not stockpiled and instead remained in the barn until removal and direct spreading, $\mathrm{CH}_{4}$ and direct and indirect $\mathrm{N}_{2} \mathrm{O}$ emissions from the waste would amount to 0.009 and $0.09 \mathrm{~kg}$ of $\mathrm{CO}_{2} \mathrm{e} / \mathrm{kg}$ of FPCM, respectively. This represents a $51 \%$ decrease in manure emissions and would reduce the farm's total carbon footprint by $11 \%$ (from 0.89 to $0.80 \mathrm{~kg}$ of $\mathrm{CO}_{2} \mathrm{e} / \mathrm{kg}$ of $\mathrm{FPCM}$ ).
Supplementary Feed. Replacing 50 or $100 \%$ avon and dried distillers grains with lower embodied carbon feeds (those that require less carbon emissions to produce and transport), such as brewers grain or maize grain, led to a decrease in the carbon footprint of supplementary feed, ranging from 30 to $85 \%$ (Figure 4). The effect of supplementary feed choice on the overall carbon footprint of goat milk can be significant, with the scenarios showing a reduction in the total carbon footprint of between 11 and 30\%, although the effect of different supplementary feeds on $\mathrm{N}_{2} \mathrm{O}$ excreta could offset some of this reduction.

\section{DISCUSSION}

The choice of functional unit affected our results; in this case, farms with the higher carbon footprint per

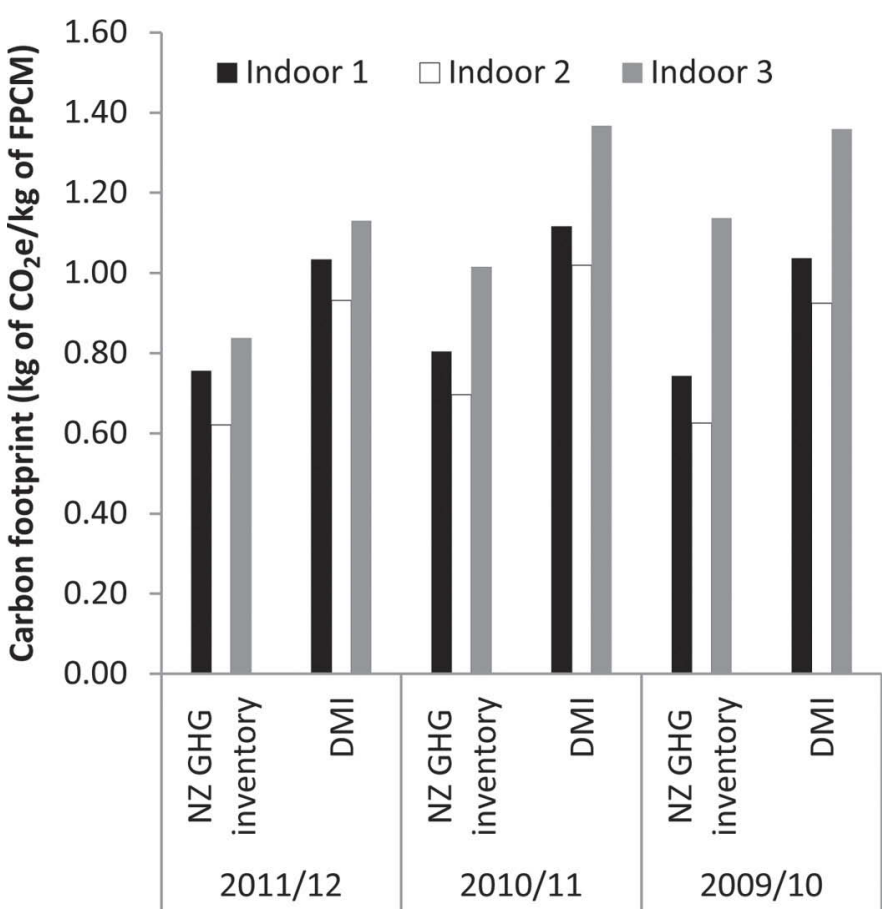

Figure 3. Effect of enteric methane methodology on the carbon footprint. $\mathrm{CO}_{2} \mathrm{e}=\mathrm{CO}_{2}$ equivalents; FCPM = fat- and protein-corrected milk; $\mathrm{GHG}=$ greenhouse gas. 
Table 10. Effect of varying $\mathrm{N}$ contents of manure on $\mathrm{N}_{2} \mathrm{O}$ emissions, Indoor 1 (yr 1)

\begin{tabular}{lcc}
\hline $\mathrm{N}$ content of manure & $\begin{array}{c}\mathrm{N}_{2} \mathrm{O} \text { emissions from manure } \\
\left(\mathrm{kg} \text { of } \mathrm{CO}_{2} \text {-equivalents/kg of }\right. \\
\text { fat- and protein-corrected milk) }\end{array}$ & $\begin{array}{c}\text { Total farm emissions } \\
\left(\mathrm{kg} \text { of } \mathrm{CO}_{2} \text {-equivalents } / \mathrm{kg}\right. \\
\text { of fat-and protein-corrected milk) }\end{array}$ \\
\hline $13.6 \mathrm{~kg}$ of N/doe, $10.4 \mathrm{~kg}$ of N/buck, $2.22 \mathrm{~kg}$ of N/kid & 0.079 & 0.76 \\
$21.70 \mathrm{~kg}$ of N/goat & 0.179 & 0.86 \\
\hline
\end{tabular}

hectare had a lower carbon footprint per kilogram of FPCM. In some countries where land area is a limiting factor, it may be appropriate to compare farms using a functional unit based on land area. However, in New Zealand, land is not a limiting factor, so most of our results were compared on a production basis (per kilogram of FPCM).

Primary production systems typically vary regionally, between farms, and annually. In New Zealand, the majority $(90 \%)$ of dairy goat farms are in within a small $\left(25,000 \mathrm{~km}^{2}\right)$ geographical region, so regional variability is not relevant. The dairy goat farms in our study had, on average, lower stocking and milk solid production per head compared with the industry average. These differences may be partly explained by different proportions of indoor and outdoor farms. The industry average is based on a greater proportion of indoor farms that tend to have more goats and higher production per goat. The number of farms that need to be sampled to provide an industry-average carbon footprint is influenced by variability between farms.

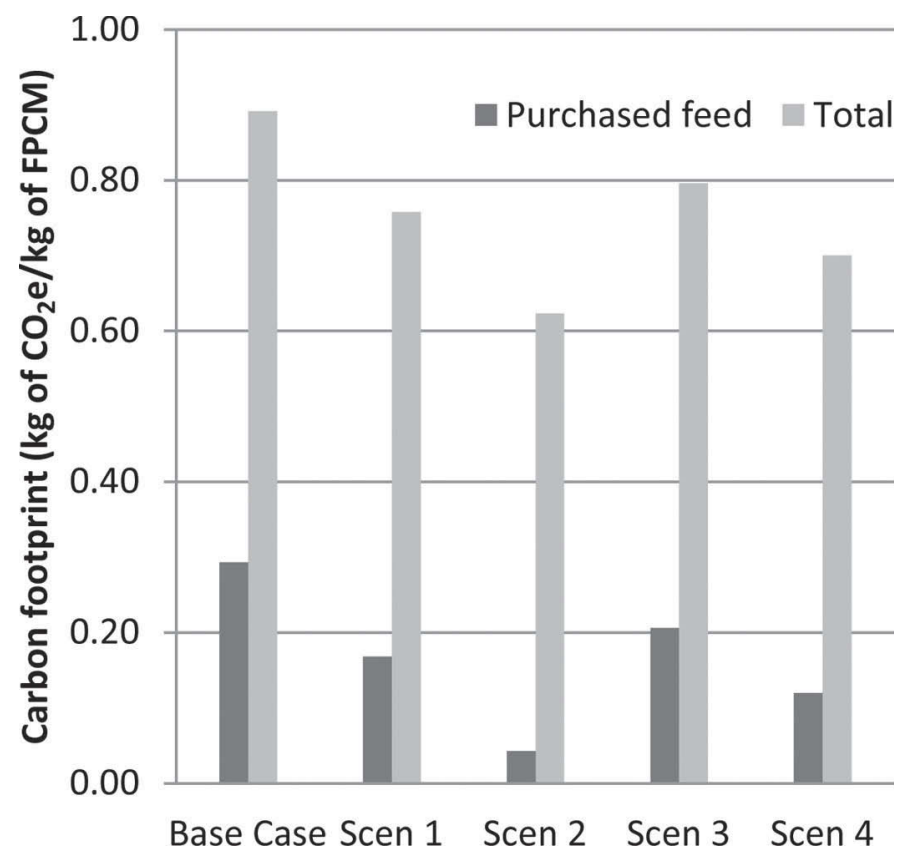

Figure 4. Carbon footprint of purchased feed scenarios. $\mathrm{CO} 2 \mathrm{e}=$ $\mathrm{CO}_{2}$ equivalents; $\mathrm{FCPM}=$ fat- and protein-corrected milk.
Between-farm variability results from differing farm management systems and can be attributed to several factors, including goat stocking rates, fertilizer programs, manure management, as well as the amount and type of supplementary feed bought.

Annual variability can be addressed by using data from more than 1 yr. Eady and Ridoutt (2009) suggest a reporting period of $3 \mathrm{yr}$ is appropriate for agricultural systems, whereas 2 yr has been suggested as a minimum (Harris and Narayanaswamy, 2009). This dairy goat study covered $3 \mathrm{yr}$ for both the indoor and outdoor systems, although data were available for all 5 farms in only 2 yr. For these 2 yr, the average carbon footprint of the 5 farms was not significantly different from the 3-yr average for all farms.

Methane from enteric fermentation is a major contributor to the carbon footprint. This is common for dairy farm systems (Cederburg and Mattsson, 2000; Thomassen et al., 2007). The enteric fermentation emission factors used in our study were New Zealand dairy goat-specific for both methods 1 and 2. These are much higher than the Tier 1 IPCC default, which reports $5 \mathrm{~kg}$ of $\mathrm{CH}_{4} /$ head per year for a $40-\mathrm{kg}$ goat (IPCC, 2006). This is to be expected, as the IPCC emission factor is not for dairy goats that lactate for more than $300 \mathrm{~d} / \mathrm{yr}$ specifically, but was based on Crutzen et al. (1986), who used data from a mixed population (meat, milk, and fiber breeds) of Indian goats with a gross energy intake estimate of $14 \mathrm{MJ} /$ goat per day and $6 \% \mathrm{CH}_{4}$ yield. Given that methane has such a large effect on the carbon footprint, it is appropriate to use New Zealand-specific information. Method 1 relies heavily on an estimation of the amount of DM consumed by the goats. It was initially chosen as it would provide farm-specific enteric methane data (i.e., emissions from the actual animals of the farms assessed, as it calculates enteric methane based on the feed consumed). Very good information was available for the indoor farming systems on the amount of feed produced on farm and purchased. The factor that is not as well known, however, is how much of that the goats actually eat. The current study assumed 80 to $90 \%$ based on anecdotal industry evidence, but this value has not been validated. In our study, method 1 gave a DMI estimate of 740 to $880 \mathrm{~kg} / \mathrm{head}$ per year and an implied emission factor of 15 to $17 \mathrm{~kg}$ of $\mathrm{CH}_{4} /$ head 
per year, at least 3 times higher than the IPCC (2006) default. Method 2 used an energy requirements model for a range of goat classes and estimated DMI at 305 to $461 \mathrm{~kg} /$ head per year. This provides emission factors of $9.60 \mathrm{~kg}$ of $\mathrm{CH}_{4} /$ head per year for milking does and 7.35 $\mathrm{kg}$ of $\mathrm{CH}_{4} /$ head per year for bucks (Lassey, 2012). The shortcoming of method 2, however, is the fact that the emission factors are derived from modeling performed on the entire New Zealand population of milking goats (i.e., is not specific to the goats of the present study). Method 1 overestimated DMI substantially compared with method 2, and this is likely due to the unverified assumptions around the consumption of feed in method 1 . For this reason, method 2 is likely to provide moreaccurate estimates of enteric methane emissions.

The choice of economic or physical causality allocation method did not significantly change the goat milk carbon footprint. The main aim of the dairy goat farming systems is to produce milk with very few animals being used for meat; therefore, very low allocation of the carbon footprint to meat was observed. This is decreased further when economic allocation was used, as milk products provide better revenue than meat products. The International Dairy Federation (2010) allocation methodology for physical causality used in the current scenario analysis is based on dairy cow feed requirements rather than dairy goat feed requirements, which may have a different underlying use of feed for meat and milk.

The nitrogen content of manure changes with quantity and type of feed the goats are eating and can have a significant effect on the carbon footprint. Only 1 farm had independent analysis of the $\mathrm{N}$ in its barn manure, but the results were significantly higher than the values used in the New Zealand GHG inventory. More information on the effect of feed type on $\mathrm{N}$ content of manure is needed to provide a more robust carbon footprint.

In years when it was applied, lime substantially increased the carbon footprint. Dairy goat farms typically apply lime many years apart, and it may be more appropriate for future assessments to spread the burden over the years between applications. The choice of manure management is one area that farmers can influence to reduce emissions. Reducing the amount of manure stockpiled, the time manure spends in a stockpile, and spreading manure on the farm more regularly will all reduce the carbon footprint.

Supplementary feed can also contribute significantly to the carbon footprint, although this can be managed by varying the choice of feed, as the scenario analyses of supplementary feeds illustrate. A simple feed substitute, such as replacing dried distillers grain and avon with brewers grain, could reduce the overall farm foot- print by $30 \%$ depending on farm management systems. Many of the supplementary feeds are by-products of other processes; therefore, emissions must be allocated between products. The priority for allocation approaches (ISO, 2006b) is to avoid allocation through (1) division into subprocesses or use of system expansion; (2) physical relationship, such as mass or volume; or (3) economic value. We have chosen to use economic allocation as outlined by the International Dairy Federation (2010) guidelines due to difficulties with dividing the systems into subprocesses, identification of products substituted by the by-products for system expansion, and identification of an appropriate physical relationship applicable across all feed types.

Studies on the carbon footprint of dairy goat systems are not common. Kanyarushoki et al. (2008) estimated the carbon footprint of dairy goat farms in central-western France using data from 6 farms over 1 yr to be 3.70 $\mathrm{t}$ of $\mathrm{CO}_{2} \mathrm{e} / \mathrm{ha}$ and $1.27 \mathrm{~kg}$ of $\mathrm{CO}_{2} \mathrm{e} / \mathrm{kg}$ of $\mathrm{FPCM}$. Our New Zealand study covered 5 farms over 3 yr and the carbon footprint was of a similar magnitude in terms of kilograms of FPCM, but more than double in terms of tonnes of $\mathrm{CO}_{2} \mathrm{e}$ per hectare. Michael (2011) estimated the cradle-to-gate carbon footprint of an average Australian dairy goat farm at $5.22 \mathrm{~kg}$ of $\mathrm{CO}_{2} \mathrm{e} / \mathrm{kg}$ of FPCM. This is a substantially higher carbon footprint estimate per kilogram of FPCM than in our New Zealand study. The Australian study uses the IPCC (2006) default enteric methane emission factor (which is substantially lower than that used in our study) and assumed milk production of $561 \mathrm{~kg} /$ milked doe per year, whereas in our study, milk production varied from 621 to $966 \mathrm{~kg} /$ milked doe per year. Together these do not explain the large difference in results.

Unlike the situation with dairy goat farms, carbon footprint analyses on dairy cow farms are plentiful. Dairy cow milk is the common alternative to goat milk in New Zealand, and carbon footprint estimates of the New Zealand dairy cow carbon footprint vary from 0.63 (Flysjö et al., 2011) to $1.12 \mathrm{~kg}$ of $\mathrm{CO}_{2} \mathrm{e} / \mathrm{kg}$ of $\mathrm{FPCM}$ (Basset-Mens et al., 2009). The New Zealand dairy goat carbon footprint, as determined in our study, was of a similar magnitude.

\section{CONCLUSIONS}

Globally, there is a lack of data on the carbon footprint of dairy goat milk production. Values that are available vary significantly, although the reasons for this are diverse and the interactions complex. A standard method and greater certainty about country- and system-specific factors for dairy goat milk production are needed if carbon footprints are to be compared. The average cradle-to-gate carbon footprint of 5 dairy 
goat farms over 3 yr in New Zealand was estimated at $8.78 \mathrm{t}$ of $\mathrm{CO}_{2} \mathrm{e} / \mathrm{ha}$ and $0.90 \mathrm{~kg}$ of $\mathrm{CO}_{2} \mathrm{e} / \mathrm{kg}$ of $\mathrm{FPCM}$. The carbon footprint varied by farm, year, and farming system (indoor or outdoor). The outdoor farms had a significantly lower carbon footprint compared with indoor farms per hectare of land use but were not significantly different when comparing results per kilogram of FPCM. The major contributors to the carbon footprint were methane from enteric fermentation, supplementary feed production, and transport and nitrous oxide from manure management. The choice of methodology used to calculate methane emissions from enteric fermentation can have a substantial effect on the carbon footprint. Using economic or physical causality to allocate the carbon burden to milk and meat had little effect on the average indoor farm goat milk carbon footprint, largely due to the low use of animals for meat products. Several management options are available that could reduce the carbon footprint, including reduced fertilizer application, changes to supplementary feed, and changes in manure management.

\section{ACKNOWLEDGMENTS}

This study was funded by Dairy Goat Cooperative (DGC) NZ Ltd. (Hamilton, New Zealand), who assisted with the study aims, scope, and data collection. Thanks to Colin Prosser of DGC for his assistance in data collection and answering our sometimes-odd questions about dairy goat farming practices. Thanks to Marlies Zonderland-Thomassen of AgResearch Ltd., Hamilton, New Zealand, for her assistance with the scope and functional unit choices in particular.

\section{REFERENCES}

Barber A. 2009. NZ fuel and electricity-Total primary energy use, carbon dioxide and GHG emission factors. Paper for Ministry of Economic Development by AgriLINK NZ Ltd., Kumeu, New Zealand.

Basset-Mens, C., F. M. Kelliher, S. Ledgard, and N. Cox. 2009. Uncertainty of global warming potential for milk production on a New Zealand farm and implications for decision making. Int. J. Life Cycle Assess. 14:630-638. http://dx.doi.org/10.1007/s11367009-0108-2.

Carlson, B., B. Tikkisetty, and A. Duncan. 2010. Development of best nutrient management practices for dairy goat farming systems. Pages 245-252 in Farming's Future: Minimising Footprints and Maximising Margins. L. D. Currie and C. L. Christensen, ed. Occasional Report No. 23. Fertilizer and Lime Research Centre, Massey University, Palmerston North, New Zealand.

Cederberg, C., and B. Mattsson. 2000. Life cycle assessment of milk production: A comparison of conventional and organic farming. J. Clean. Prod. 8:49-60.

Clark, J., D. K. Beeded, and R. A. Erdman. 2001. Nutrient Requirements of Dairy Cattle. 7th rev. ed. Natl. Acad. Press, Washington, DC.

Crutzen, P. J., I. Aselmann, and W. Seiler. 1986. Methane production by domestic animals, wild ruminants, other herbivorous fauna, and humans. Tellus 38:271-284.
DEFRA. 2011. 2011 Guidelines to DEFRA/DECC's GHG conversion factors for company reporting. Accessed Aug. 12, 2012. www. gov.uk/government/uploads/system/uploads/attachment_data/ file/69314/pb13625-emission-factor-methodology-paper-110905. pdf.

Eady, S. J., and B. G. Ridoutt. 2009. Setting reporting periods, allocation methods and system boundaries for Australian agricultural life cycle assessment. In Proc. 6th Australian Conf. Life Cycle Assessment - Sustainability Tools for a New Climate. Accessed Aug. 30, 2013. http://conference.alcas.asn.au/2009/Eady\%20and\%20Ridoutt.pdf

Flysjö, A. C. Cederburg, M. Henriksson, and S. Ledgard. 2011. How does co-product handling affect the carbon footprint of milk? Case study of milk production in New Zealand and Sweden. Int. J. Life Cycle Assess. 16:420-430. http://dx.doi.org/10.1007/s11367-0110283-9.

Harris, S., and V. Narayanaswamy. 2009. Review of Australian and international agricultural life cycle assessment examples. Report prepared for Rural Industries Research and Development Corporation, Canberra, Australia.

Holmes, C. W. I. M. Brookes, D. J. Garrick, D. D. S. MacKenzie, T. J. Parkinson, and G. F. Wilson. 2007. Milk Production from Pasture: Principles and Practices. Massey University, Palmerston North, New Zealand.

International Dairy Federation. 2010. A common carbon footprint approach for dairy. The IDF guide to standard lifecycle assessment methodology for the dairy sector. Bulletin of the IDF, 445/2010. Accessed Feb. 26, 2013. http://idf-lca-guide.org/Files/media/ Documents/445-2010-A-common-carbon-footprint-approach-fordairy.pdf.

IPCC. 1995. Climate Change 1995: The Science of Climate Change. Contribution of Working Group I to the Second Assessment of the Intergovernmental Panel on Climate Change. J. T. Houghton, L. G. Meira Filho, B. A. Callender, N. Harris, A. Kattenberg, and K. Maskell, ed. Cambridge University Press, Cambridge, UK.

IPCC. 2006. IPCC Guidelines for National Greenhouse Gas Inventories. Prepared by the National Greenhouse Gas Inventories Programme. H. S. Eggleston, L. Buendia, K. Miwa, T. Ngara, and K. Tanabe, ed. IGES, Kanagawa, Japan.

IPCC. 2013. Summary for Policymakers. In Climate Change 2013: The Physical Science Basis. Contribution of Working Group I to the Fifth Assessment Report of the Intergovernmental Panel on Climate Change. T. F. Stocker, D. Qin, G.-K. Plattner, M. Tignor, S.K. Allen, J. Boschung, A. Nauels, Y. Xia, V. Bex, and P.M. Midgley, ed. Cambridge University Press, Cambridge, UK.

ISO. 2006a. ISO14040: Environmental management—Life cycle assessment-Principles and framework. International Organization for Standardization, Geneva, Switzerland.

ISO. 2006b. ISO14044: Environmental Management—Life cycle assessment-Requirements and guidelines. International Organization for Standardization, Geneva, Switzerland.

ISO. 2013. ISO/TS 14067. Greenhouse gases-Carbon footprint of products-Requirements and guidelines for quantification and communication. International Organization for Standardization, Geneva, Switzerland.

Kanyarushoki, C., F. Fuchs, and H. M. G. van der Werf. 2008. Environmental evaluation of cow and goat milk chains in France. Proc. 6th Int. Conf. LCA in the Agricultural-Food Sector, Zurich, Switzerland. T. Nemecek and G. Gaillard, ed. Agroscope ReckenholzTanikon Research Station, Zurich, Switzerland.

Lassey, K. 2012. Methane emissions and nitrogen excretion rates for New Zealand goats. MAF Technical Paper No: 2012/13. Report prepared for Ministry of Agriculture and Forestry by NIWA. Accessed Jun. 24, 2013. https://www.mpi.govt.nz/documentvault $/ 2954$.

Ledgard, S. F., M. Boyes, and F. Brentrup. 2011. Life cycle assessment of local and imported fertilisers used on New Zealand farms. In Adding to the Knowledge Base for the Nutrient Manager. L. D. Currie and C. L. Christensen, ed. Occasional Report No. 24, Fertilizer and Lime Research Centre, Massey University, Palmerston North, New Zealand. 
Michael, D. 2011. Carbon reduction benchmarks and strategies-New animal products. RIRDC Publication No. 11/063. Accessed Jul. 23, 2013. https://rirdc.infoservices.com.au/downloads/11-063.

Ministry of Agriculture and Forestry. 2011. Carbon footprint of New Zealand arable production-Wheat, maize silage, maize grain and ryegrass seed. MAF Technical Paper No: 2011/97 Accessed Jun. 11, 2013. https://www.mpi.govt.nz/document-vault/4018.

Ministry for the Environment. 2013, New Zealand's GHG inventory 1990-2011. Accessed May 19, 2013. http://www.mfe.govt.nz/publications/climate/greenhouse-gas-inventory-2013/index.html.

National Renewable Energy Laboratory. 2014. US life cycle inventory database. Accessed Feb. 11, 2014. https://www.lcacommons.gov/ nrel/search.

Renouf, M., and M. Wegener. 2011. Life cycle assessment of Australian sugarcane products, with a focus on cane processing. Int. J. Life Cycle Assess. 16:125-137. http://dx.doi.org/10.1007/s11367-0100233-y.

Sandilands, J., B. Nebel, C. Hodgson, and P. Hall. 2009. Greenhouse gas emissions of the Forestry Sector in New Zealand. MAF Report. Scion, Rotorua, New Zealand.

Sonesson, U., C. Cederburg, and M. Berglund. 2009. Greenhouse gas emission in animal feed production. Accessed February 15, 2014. http://www.klimatmarkningen.se/wp-content/ uploads/2009/12/2009-2-feed.pdf.
Thomassen, M. A., K. J. van Calker, M. C. J. Smits, G. L. Iepema, and I. J. M. I.de Boer. 2007. Life cycle assessment of conventional and organic milk production in the Netherlands. Agric. Syst. 96:95-107.

Vellinga, T. H., H. Blonk, M. Marinussen, W. J. van Zeist, I. J. M. de Boer, and D. Starmans. 2013a. Methodology used in FeedPrint: A tool quantifying greenhouse gas emissions of feed production and utilization. Wageningen UR Livestock Research. Accessed Feb. 6, 2014. http://edepot.wur.nl/254098.

Vellinga, T. H., H. Blonk, M. Marinussen, W. J. van Zeist, I. J. M. de Boer, and D. Starmans. 2013b. FeedPrint: A tool quantifying greenhouse gas emissions of feed production and utilization. Wageningen UR Livestock Research. Accessed Feb. 10, 2014. http:// webapplicaties.wur.nl/software/feedprint/.

Wells, C. 2001. Total energy indicators of agricultural sustainability: Dairy farming case study. University of Otago. MAF Policy Technical Paper 2001/3. Accessed Jun. 10, 2012. http://maxa.maf. govt.nz/mafnet/publications/techpapers/techpaper0103-dairyfarming-case-study.pdf.

Wheeler, D. M. 2012. Overseer technical manual, calculation of methane emissions. Accessed Jun. 10, 2013. http://overseer.org.nz/ technical-information. 